\title{
MOOC in a Malaysian university: preliminary perceptions and perspectives
}

\section{Nor Shazmira Zulkafli* and Fitri Suraya Mohamad}

Department of Cognitive Sciences, Faculty of Cognitive Sciences and Human Development, Universiti Malaysia Sarawak, Malaysia

Email: shazmirazulkafli@gmail.com

Email: mfitri@unimas.my

*Corresponding author

\begin{abstract}
MOOC is gaining momentum in Malaysia as it is seen as a game changer in the delivery of university courses to a wider audience, beyond the campus walls. At Universiti Malaysia Sarawak, the first MOOC course was designed and developed to deliver learning about ICT competencies to university students at all public universities throughout the country. The study examined the perceptions and satisfaction levels among on-campus students who have enrolled into the MOOC course, as a first step to investigate the impact of the web-based instructional approach on higher learning. Two key aspects were focused; the pedagogical and technical assembly of the MOOC. The pedagogical aspect looked into the instructional design and assessment of contents in the course, while the technical aspect covered areas such as user interface, presentation of video content, provision of learning and social tools, and learning analytics. Findings indicated a significant relationship between each of these elements with participants' satisfaction levels. It is clear that these elements are crucial in making MOOC a successful instructional supplement for undergraduate learning in Malaysia.
\end{abstract}

Keywords: massive open online courses; MOOCs; higher education; student satisfaction; university learning.

Reference to this paper should be made as follows: Zulkafli, N.S. and Mohamad, F.S. (2018) 'MOOC in a Malaysian university: preliminary perceptions and perspectives', Int. J. Innovation and Learning, Vol. 24, No. 3, pp.262-276.

Biographical notes: Nor Shazmira Zulkafli studied cognitive science at the Faculty of Cognitive Science and Human Development, Universiti Malaysia Sarawak. She graduated in 2015, and is currently working as an analyst at an outsourcing company in Selangor, Malaysia. She is interested in learning with technology, particularly multimedia technology and e-learning.

Fitri Suraya Mohamad holds a Doctorate from the Institute of Education, London, UK. She is currently an Associate Professor at the Faculty of Cognitive Sciences and Human Development, Universiti Malaysia Sarawak. She has presented and published widely on topics related to educational technology, teacher knowledge, and remote rural education for children. 